\title{
Empirical Equation for Concrete Made With PPC or OPC with Fly Ash by Accelerated Mix Design Method
}

\author{
Ojha P N, Suresh Kumar, Manish Mandre, Piyush Mittal, Brijesh Singh*, Arora V V
}

National Council for Cement and Building Materials, India

* Corresponding Author: brijeshsehwagiitr96@gmail.com

Received: 11-08-2021

Accepted: 02-11-2021

\begin{abstract}
Assessment of 28 days strength from accelerated strength (1 day) can be extremely helpful. Early prediction of 28 days compressive strength is required basically for two purposes. First, to finalize the concrete mix proportions in the laboratory and secondly, for quality control purpose during construction. Through this concept designers can easily identify the uncalculated errors during mix design or variations in materials and exposure conditions etc. and take necessary correction and modification measures to attain the desired strengths at 28 days. As per IS: 9013 methodology to predict the 28 days strength of concrete from accelerated cured strength are indicated only for normal/control concrete. In the past few year focus has shifted from Ordinary Portland Cement (OPC) to Portland Pozzolana Cement (PPC). Fly ash is also being used widely at sites as replacement of OPC. However, there is no such guideline available by which the assessment of 28 days strength of Indian fly ash concrete can be made from accelerated strength tests. In the present study an attempt has been made to predict the expected 28 days compressive strength of concrete having PPC or OPC with fly ash using accelerated temperature regime methods. The experimental study includes the use of 2 brands of PPC, 5 brands of OPC and 2 sources of fly ash for replacement of OPC ranging from $20 \%$ to $45 \%$. Two temperature regimes $90{ }^{\circ} \mathrm{C}$ and $82^{\circ} \mathrm{C}$ were used for accelerated curing. The samples were cured for 7.5 hours and 20hours respectively in each regime for expected 28 day compressive strength. The mathematical equations to estimate the 28 days compressive strength of concrete, cured at $90^{\circ} \mathrm{C}$ for 7.5 hours for mixes having PPC, OPC mixed with fly ash $20 \%$ to $35 \%$ is $\mathrm{f}_{\exp } 28=1.223 \mathrm{f}_{\text {acs }}+2.024$. The mathematical equations to estimate the 28 days compressive strength of concrete, cured at $90^{\circ} \mathrm{C}$ for 7.5 hours for mixes having PPC, OPC mixed with fly ash more than $35 \%$ and up to $45 \%$ is $\mathrm{f}_{\exp } 28=0.993 \mathrm{f}_{\text {acs }}+6.044$.
\end{abstract}

Keywords: Mix Design, Accelerated Method, PPC, Compressive Strength, Mathematical Equation.

\section{Introduction}

According to Indian Standard acceptance and rejection of any type of concrete should be done by determining 28 days compressive strength (IS- 456, 2000). It was observed that normal concrete achieve its potential strength within this time period. But for fly ash concrete, 28 days strength does not yield its potential strength as its rate of strength development is significantly slower compared to normal concrete. Potential strength of fly ash concrete may develop at 90 days or even after 180 days (Tokyay, 1999). It is also known that the strength of normally cured concrete at 28 days is considered for structural design. This time difference may lead to loss of valuable time and money. Accelerated curing of normal concrete by warm water method and boiling water method provided by IS:9013 (1978) are helpful to predict 28 days strength of control concrete with respect to accelerated cured strength by means of correlation between accelerated strength and normal curing strength. For the prediction of 28 days strength of fly ash concretes no such correlation is available. In this current paper provides some strength prediction models have been proposed (Jayanta and Jaydeep, 2016). 
Construction projects go through time overrun and cost overrun, due to delay in decision making in appropriate time frame. Many activities are involved in execution of a project. Finalization of concrete mix proportions is the most important activity. Usually 28 days moist cured compressive strength test results are required to finalize concrete mix proportions (Udoeyo et al., 2010). The guidelines and procedures given in IS 9013: 1978 which is based on elevated temperature curing method helps in early decision making about mix proportions within 48 to 72 hours when mix has OPC as cementing material.

In past few years, focus has shifted from OPC to a wider application of blended cement such as PPC, PSC etc. Many industrial by products are being used as supplementary cementitious materials and fly ash is one of them. Fly ash is used in two ways, one in cement industry as part of cement itself i.e. as PPC and another as part replacement of OPC during concrete mix design. However no empirical formula or guidelines are available for predicting 28 days moist cured compressive strength concrete having PPC or OPC with fly ash as binder (Nikitha and Kameswara, 2019).

It is well established that an increase in curing temperature increases the rate of hydration of cement. The increase in rate of hydration reaction and strength development of OPC, at elevated curing temperature is also well documented in existing literatures (Shelke and Gadve, 2013). The use of fly ash and other supplementary cementitious material is increasing not only due to an economic and sustainability point of view but also these materials improve the rheology of concrete and other engineering properties of hardened concrete. However the rate of strength gain in OPC with fly ash concrete is slower than in concrete with OPC only (Bhanja and Pan, 2013; Jayadevan et al., 2014).

Fly ash is used in concrete mix generally to reduce the heat of hydration but because of this there is reduction in early strength development of concrete. Many parameters affect the strength of concrete such as quantum of fly ash, quality and quantity of binder material, aggregate size, curing regime, chemical effect, concrete grade used and mix proportions. Hydration itself is affected by the temperature (Khan et al., 2019; Krishna et al., 2010). To accelerate the strength gain at early age and to relate it to the 28-days compressive strength, proper trend lines and calibration curves are needed. For the accelerated curing of concrete, different methods and techniques have been classified earlier also such as maturity methods, curing in oven, curing in heated water and expanded polystyrene molds method (Amritkar and More, 2015, Shah and BhavnaShah, 2011). In such scenario, there is need to develop the mathematical equations to determine strength of concrete which will generate confidence to the construction fraternity for use of concrete made with blended cement by using accelerated curing method.

A number of methods of accelerated and early age testing of cubes have been developed that allow early prediction to be made of strength development at later ages. Indian standard IS: 9013 covers two methods. In warm water method the concrete specimens are cured at elevated temperature of $55 \pm 2^{\circ} \mathrm{C}$ for 19 hours 50 minutes and in boiling water method the concrete specimens are cured at elevated temperature of $100^{\circ} \mathrm{C}$ for $3.5 \mathrm{~h} \pm 5$ minutes. Expected 28 days compressive strength is calculated by empirical formula given in the code. It is found that the above two methods are useful for prediction of expected 28 days compressive strength when concrete is made using OPC.

BS 1881(1983) covers three methods of accelerated curing, under which the concrete specimens are cured at elevated temperature of $35^{\circ} \mathrm{C}, 55^{\circ} \mathrm{C}$ and $82^{\circ} \mathrm{C}$ for 24 hours \pm 15 minutes, 20 hours \pm 10 minutes, and 14 hours \pm 15 minutes respectively.

Similarly ASTM C-684 (ACI 214.1R, 1987; ASTM C 684, 1999) covers 4 procedures for estimation of 28 days compressive strength. In warm water method concrete specimens are cured at elevated temperature of $35^{\circ} \mathrm{C}$ for 23.5 hours \pm 30 minutes, in boiling water method at $100^{\circ} \mathrm{C}$ for 
3.5hours \pm 5 minutes, in Autogenous method at $21 \pm 6^{\circ} \mathrm{C}$ for 48 hours \pm 15 minutes and in high temperature and pressure method, the concrete specimens are cured at $150^{\circ} \mathrm{C} \& 10.3 \pm 0.2 \mathrm{MPa}$ pressure for 5 hours \pm 5 minutes.

Canadian standard CSA A23.1 (1970) has an establish procedure, which is independent of cement type, mix proportion and admixture type. In this method, the concrete specimens are cured at elevated temperature of $100^{\circ} \mathrm{C}$ for 16 hours once the concrete is finally set after casting.

The methods given in BS: 1881 \& ASTM C 684 recommend, to develop appropriate correlation using accelerated compressive strength and actual 28 days compressive strength for the materials and mix used. They do not provide any general empirical relationship to predict the expected 28 days compressive strength.

NCB has conducted this experimental study to develop a simple empirical relationship between accelerated compressive strength and 28 days moist cured compressive strength of concrete cubes. The objective of this research is to develop guidelines to determine the expected 28 days compressive strength of concrete having PPC or OPC with fly ash as cementitious material using accelerated curing. The developed method can also be used at site for quality control purposes.

\section{Materials}

\subsection{Cement}

Five brands of OPC-43 grade cements designated as OPC-I, OPC-II, OPC-III, OPC-IV and OPC-V conforming to IS: 269 (2015) and two brands of PPC designated as PPC-I \& PPC-II conforming to IS: 1489 (2015) were used for the experimental work. All the cements were tested as per IS: 4031 and IS: 4032. The test results of physical and chemical analysis are given in Table-1.

\subsection{Flyash}

Two flyash samples from different sources designated as Fly ash 1 and Fly ash 2 were used in the experimental work. The fly ash samples were tested as per IS: 1727: 1967 and the results were conforming to IS 3812 (2013). The tests results are given in Table-2.

Table 1. Test results of cement sample Ordinary Portland Cement (OPC) and Portland Pozzolana Cement (PPC)

\begin{tabular}{|l|l|l|l|l|l|l|l|l|}
\hline S.No. & Properties & OPC1 & OPC2 & OPC3 & OPC4 & OPC5 & PPC1 & PPC2 \\
\hline \hline 1 & Blain's fineness, $\left(\mathrm{m}^{2} / \mathrm{kg}\right)$ & 282 & 355 & 292 & 336 & 306 & 379 & 358 \\
\hline 2 & Setting time, (in minutes) & & & & & & & \\
& Initial & 230 & 115 & 160 & 120 & 160 & 135 & 140 \\
& Final & 280 & 180 & 215 & 195 & 210 & 205 & 210 \\
\hline 3 & Compressive Strength (N/mm $\left.{ }^{2}\right)$ & & & & & & & \\
& 3 days & 34.5 & 36.5 & 31.5 & 35.5 & 39.5 & 30.0 & 27.5 \\
& 7 days & 45.0 & 44.5 & 41.0 & 45.0 & 49.0 & 41.5 & 39.0 \\
& 28 days & 55.5 & 55.0 & 47.5 & 53.5 & 60.0 & 55.5 & 53.5 \\
\hline 4 & Soundness by Autoclave, & 0.01 & 0.05 & 0.09 & 0.04 & 0.01 & 0.07 & 0.08 \\
& \% Le Chatelier Exp (mm) & 1.50 & 0.50 & 1.0 & 1.0 & 1.0 & 2.00 & 2.00 \\
\hline 5 & Specific Gravity & 3.15 & 3.15 & 3.15 & 3.15 & 3.15 & 2.85 & 2.87 \\
\hline
\end{tabular}

Table 2. Test results of fly ash sample

\begin{tabular}{|l|l|l|l|}
\hline Sl No. & Properties & Fly ash Source 1 & Fly ash Source 2 \\
\hline \hline 1 & Blain's fineness, $\mathrm{m}^{2} / \mathrm{kg}$ & 403 & 329 \\
\hline 2 & Specific Gravity & 2.20 & 2.20 \\
\hline 3 & Lime Reactivity, $\mathrm{N} / \mathrm{mm}^{2}$ & 8.0 & 4.92 \\
\hline
\end{tabular}




\subsection{Coarse Aggregate:}

Crushed angular coarse aggregate with $20 \mathrm{~mm}$ maximum size were used in the experimental work. The coarse aggregates were tested as per IS: 2386 and were found to conform to IS: 383 (2016). The test results are given in Table - 3

\subsection{Fine Aggregate}

The fine aggregate from natural source i.e. river sand conforming to Zone-I was used in the experimental work. The fine aggregate was tested as per IS: 2386 and were found to conform to IS: 383 (2016). The test results are given in Table-4

Table 3. Test results of coarse aggregate sample

\begin{tabular}{|l|l|l|l|}
\hline Sl No. & Test Carried out & Results Obtained For $20 \mathrm{~mm}$ & Results Obtained For $10 \mathrm{~mm}$ \\
\hline \hline 1 & Specific gravity & 2.79 & 2.81 \\
\hline 2 & Water absorption \% & 0.60 & 0.40 \\
\hline 3 & Abrasion Value \% & 25.00 & 30.00 \\
\hline 4 & Crushing value \% & 25.00 & 25.00 \\
\hline 5 & Impact value $\%$ & 16.00 & 20.00 \\
\hline 6 & Flakiness index \% & 17.00 & 21.00 \\
\hline 7 & Elongation index \% & 14.00 & 13.00 \\
\hline 8 & Soundness $\left(\mathrm{Na}_{2} \mathrm{SO}_{4}\right) \%$ & 0.30 & 1.20 \\
\hline 9 & Grading & Percentage Passing & \\
\cline { 2 - 4 } & Sieve Size & $20 \mathrm{~mm}$ & $10 \mathrm{~mm}$ \\
\cline { 2 - 4 } & $40 \mathrm{~mm}$ & 100.00 & \\
\cline { 2 - 4 } & $20 \mathrm{~mm}$ & 98.00 & - \\
\cline { 2 - 4 } & $12.5 \mathrm{~mm}$ & - & 100.00 \\
\cline { 2 - 4 } & $10 \mathrm{~mm}$ & 1.00 & 68.00 \\
\cline { 2 - 4 } & $4.75 \mathrm{~mm}$ & 0 & 2.00 \\
\cline { 2 - 4 } & $2.36 \mathrm{~mm}$ & - & 0.00 \\
\hline
\end{tabular}

Table 4. Test results of fine aggregate sample (Natural)

\begin{tabular}{|l|l|l|}
\hline Sl No. & Test Carried out & Results Obtained \\
\hline 1 & Specific gravity & 2.63 \\
\hline 2 & Water absorption, \% & 1.0 \\
\hline 3 & Silt wet Sieving \% & 2.0 \\
\hline 4 & Grading & \\
\cline { 2 - 3 } & Sieve Size & Percentage Passing \\
\cline { 2 - 3 } & $10 \mathrm{~mm}$ & 100 \\
\cline { 2 - 3 } & $4.75 \mathrm{~mm}$ & 74 \\
\cline { 2 - 3 } & $2.36 \mathrm{~mm}$ & 54 \\
\cline { 2 - 3 } & $1.18 \mathrm{~mm}$ & 38 \\
\cline { 2 - 3 } & $600 \mathrm{micron}$ & 22 \\
\cline { 2 - 3 } & 300 micron & 8 \\
\cline { 2 - 3 } & 150 micron & 4 \\
\hline
\end{tabular}

\subsection{Chemical Admixture}

Superplasticizer (Normal type) conforming to IS: 9103 (1999) was used in the experimental work. 


\section{Experimental programme}

\subsection{Initial Trials}

To get the early age compressive strength through accelerated curing, some initial trials were conducted. The mix proportions used for initial trials are given in Table-5A \& Table-5B. The following parameters were fixed for initial trials:

- Three temperature regimes for accelerated curing were selected for initial trials

i. $\quad$ Boiling water with time duration of $3.5 \mathrm{~h}, 5.5 \mathrm{~h}$ and 7.5 hours.

ii. Hot water at $90^{\circ} \mathrm{C}$ temperature with time duration of $3.5 \mathrm{~h}, 5.5 \mathrm{~h}$ and $7.5 \mathrm{hours}$.

iii. Hot water at $82^{\circ} \mathrm{C}$ temperature with time duration of $16 \mathrm{~h}, 18 \mathrm{~h}, 20 \mathrm{~h}, 22 \mathrm{~h}$ and 24hours.

- One brand of OPC and fly ash from one source were used.

- Two brands of PPC were used.

- $25 \%$ OPC cement was replaced with fly ash (by weight of total cementitious materials).

Water-cement/cementitious ratio was kept $0.50,0.45$ and 0.40 .

Table 5.A. Mix proportion used for initial trials using PPC

\begin{tabular}{|c|c|c|c|c|}
\hline \multicolumn{2}{|l|}{ Mix Constituents ( kg) } & \multicolumn{3}{|c|}{ For One Cubic Meter } \\
\hline \multicolumn{2}{|l|}{ W/c ratio } & 0.50 & 0.45 & 0.40 \\
\hline \multicolumn{2}{|l|}{ Water } & 165 & 165 & 165 \\
\hline \multicolumn{2}{|l|}{ Cement } & 330 & 367 & 412 \\
\hline \multicolumn{2}{|l|}{ Chemical Admixture(Kg/cum) } & 3.30 & 3.70 & 4.10 \\
\hline \multicolumn{2}{|l|}{ Fine Aggregate(Kg/cum) } & 829 & 804 & 723 \\
\hline \multirow{2}{*}{ Coarse Aggregate (Kg/cum) } & $20 \mathrm{~mm}$ & 672 & 665 & 690 \\
\hline & $10 \mathrm{~mm}$ & 451 & 446 & 463 \\
\hline
\end{tabular}

Table 5.B. Mix proportion used for initial trials using OPC mixed with $25 \%$ flyash

\begin{tabular}{|c|c|c|c|c|}
\hline \multirow{2}{*}{\multicolumn{2}{|c|}{$\begin{array}{l}\text { Mix Constituents ( kg) } \\
\text { Water/cementitious ratio }\end{array}$}} & \multicolumn{3}{|c|}{ For One Cubic Meter } \\
\hline & & 0.50 & 0.45 & 0.40 \\
\hline \multicolumn{2}{|l|}{ Water } & 165 & 165 & 165 \\
\hline \multicolumn{2}{|l|}{ Cement } & 248 & 275 & 309 \\
\hline \multicolumn{2}{|l|}{ Fly ash (25\% as replacement) } & 82 & 92 & 103 \\
\hline \multicolumn{2}{|l|}{ Chemical Admixture(Kg/cum) } & 3.30 & 3.70 & 4.10 \\
\hline \multicolumn{2}{|l|}{ Fine Aggregate(Kg/cum) } & 829 & 796 & 750 \\
\hline \multirow{2}{*}{ Coarse Aggregate (Kg/cum) } & $20 \mathrm{~mm}$ & 672 & 671 & 673 \\
\hline & $10 \mathrm{~mm}$ & 451 & 451 & 452 \\
\hline
\end{tabular}

Based on initial trials, the results of the two methods were found encouraging:

- Accelerated curing in hot water at $90^{\circ} \mathrm{C}$ and time duration of $7.5 \mathrm{hrs}$.

- Accelerated curing in hot water at $82^{\circ} \mathrm{C}$ for longer duration of $20 \mathrm{hrs}$.

\subsection{Detailed Trials}

The detailed trials were carried out by fixing following parameters for accelerated curing.

- Accelerated curing in hot water at $90^{\circ} \mathrm{C}$ and time duration of $7.5 \mathrm{hrs}$.

- Accelerated curing in hot water at $82^{\circ} \mathrm{C}$ for longer duration of $20 \mathrm{hrs}$. 
- Five brands of OPC and flyash from two sources were used.

- Two brands of PPC were used.

- Fly ash, ranging from $20 \%$ to $45 \%$ was added (as replacement of OPC) by weight of cementitious materials.

- Water cement/cementitious ratio were kept ranging from 0.35 to 0.55 .

The mix proportions used for detailed trials are given in Table-6A to Table-6G.

\section{Detail trials}

The detail trials were carried out with two brands of PPC and five brands of OPC. Two sources of fly ash were used with $20 \%$ to $45 \%$ replacement in increment of $5 \%$. Five water-cementitious ratios were selected from 0.35 to 0.55 for detail trials. Normal type chemical admixture @ $1 \%$ by weight of cementitious material was used for all the trials.

With 5 OPC, 2 sources of fly ash and 6 replacement levels of OPC by fly ash (20\% to 45\%) a total 300 nos. of samples (one sample comprising 3 cube specimens of $150 \mathrm{~mm}$ size) were cast at various water cementitious ratios ranging from 0.55 to 0.35 . Similarly with 2 PPC, 10 samples were cast at same water cement ratios for accelerated curing under each temperature regime i.e. 310 nos. of samples were cast for regime I \& 310 nos. of samples were cast for regime II. Corresponding to accelerated cured samples, 310 nos. of samples were also cast and tested for determination of 28 days compressive strength of moist cured samples.

When accelerated curing was done the following procedures were followed:

- All specimens were cured at $27^{\circ} \mathrm{C}$ and more than $90 \%$ humidity for first 24 hours.

- All accelerated curing specimens were kept in open case after de-molding in accelerated curing tank. When accelerated curing was completed as given regime I and regime II above, they were cured at $27^{\circ} \mathrm{C}$ for two hours. Then compressive strength was determined as per procedure given in IS: 516.

Corresponding to each temperature regime, the specimens were also kept for moist curing at $27+2{ }^{\circ} \mathrm{C}$ for 28 days and after 28 days compressive strength was determined as per procedure given in IS :516.

Table 6A. Mix proportions used for detailed trials using PPC cement

\begin{tabular}{|l|l|l|l|l|l|l|}
\hline Mix Constituents (kg) & \multicolumn{5}{|l|}{ For One Cubic Meter } \\
\hline \hline W/c ratio & 0.55 & 0.50 & 0.45 & 0.40 & 0.35 \\
\hline Water & 165 & 165 & 165 & 165 & 165 \\
\hline Cement & 300 & 330 & 367 & 412 & 471 \\
\hline Chemical Admixture(Kg/cum) & 3.00 & 3.30 & 3.70 & 4.10 & 4.70 \\
\hline Fine Aggregates (Kg/cum) & 861 & 829 & 804 & 723 & 674 \\
\hline \multirow{2}{*}{ Coarse Aggregates (Kg/cum) } & $20 \mathrm{~mm}$ & 669 & 672 & 665 & 690 & 685 \\
\cline { 2 - 7 } & $10 \mathrm{~mm}$ & 449 & 451 & 446 & 463 & 460 \\
\hline
\end{tabular}

Table 6A. Mix proportions used for detailed trials using OPC mixed with $20 \%$ fly ash

\begin{tabular}{|c|c|c|c|c|c|c|}
\hline Mix Constituents ( kg) & & For & ne $\mathrm{Cl}$ & ic M & & \\
\hline Water/cementitious ratio & & 0.55 & 0.50 & 0.45 & 0.40 & 0.35 \\
\hline Water & & 165 & 165 & 165 & 165 & 165 \\
\hline Cement & & 240 & 264 & 293 & 330 & 377 \\
\hline Fly ash ( $20 \%$ as replacement) & & 60 & 66 & 73 & 83 & 94 \\
\hline Chemical Admixture(Kg/cum) & & 3.00 & 3.30 & 3.70 & 4.10 & 4.70 \\
\hline Fine Aggregates (Kg/cum) & & 863 & 831 & 798 & 753 & 704 \\
\hline Coarse Aogreoates $/ \mathrm{Kg} / \mathrm{cun}$ & & 671 & 674 & 673 & 675 & 672 \\
\hline & 10 & 451 & 452 & 452 & 453 & 451 \\
\hline
\end{tabular}


Table 6C. Mix proportions used for detailed trials using OPC mixed with $25 \%$ fly ash

\begin{tabular}{|c|c|c|c|c|c|c|}
\hline \multirow{2}{*}{\multicolumn{2}{|c|}{$\begin{array}{l}\text { Mix Constituents ( kg) } \\
\text { Water/cementitious ratio }\end{array}$}} & \multicolumn{5}{|c|}{ For One Cubic Meter } \\
\hline & & 0.55 & 0.50 & 0.45 & 0.40 & 0.35 \\
\hline \multicolumn{2}{|l|}{ Water } & 165 & 165 & 165 & 165 & 165 \\
\hline \multicolumn{2}{|l|}{ Cement } & 225 & 247 & 275 & 310 & 353 \\
\hline \multicolumn{2}{|l|}{ Fly ash (25\% as replacement) } & 75 & 83 & 92 & 103 & 118 \\
\hline \multicolumn{2}{|l|}{ Chemical Admixture(Kg/cum) } & 3.00 & 3.30 & 3.70 & 4.10 & 4.70 \\
\hline \multicolumn{2}{|l|}{ Fine Aggregates (Kg/cum) } & 861 & 829 & 795 & 750 & 700 \\
\hline \multirow{2}{*}{ Coarse Aggregates (Kg/cum) } & $20 \mathrm{~mm}$ & 669 & 671 & 671 & 672 & 668 \\
\hline & $10 \mathrm{~mm}$ & 449 & 451 & 450 & 451 & 449 \\
\hline
\end{tabular}

Table 6D. Mix proportions used for detailed trials using OPC mixed with $30 \%$ fly ash

\begin{tabular}{|c|c|c|c|c|c|c|}
\hline \multirow{2}{*}{\multicolumn{2}{|c|}{$\begin{array}{l}\text { Mix Constituents ( kg) } \\
\text { Water/cementitious ratio }\end{array}$}} & \multicolumn{5}{|c|}{ For One Cubic Meter } \\
\hline & & 0.55 & 0.50 & 0.45 & 0.40 & 0.35 \\
\hline \multicolumn{2}{|l|}{ Water } & 165 & 165 & 165 & 165 & 165 \\
\hline \multicolumn{2}{|l|}{ Cement } & 210 & 231 & 257 & 289 & 330 \\
\hline \multicolumn{2}{|l|}{ Fly ash (30\% as replacement) } & 90 & 99 & 110 & 124 & 141 \\
\hline \multicolumn{2}{|l|}{ Chemical Admixture(Kg/cum) } & 3.00 & 3.30 & 3.70 & 4.10 & 4.70 \\
\hline \multicolumn{2}{|l|}{ Fine Aggregates (Kg/cum) } & 858 & 826 & 792 & 746 & 697 \\
\hline \multirow{2}{*}{ Coarse Aggregate (Kg/cum) } & $20 \mathrm{~mm}$ & 667 & 669 & 668 & 669 & 665 \\
\hline & $10 \mathrm{~mm}$ & 448 & 449 & 449 & 450 & 447 \\
\hline
\end{tabular}

Table 6E. Mix proportions used for detailed trials using OPC mixed with $35 \%$ fly ash

\begin{tabular}{|c|c|c|c|c|c|c|}
\hline \multicolumn{2}{|l|}{ Mix Constituents ( kg) } & \multicolumn{5}{|c|}{ For One Cubic Meter } \\
\hline \multicolumn{2}{|l|}{ Water/cementitious ratio } & 0.55 & 0.50 & 0.45 & 0.40 & 0.35 \\
\hline \multicolumn{2}{|l|}{ Water } & 165 & 165 & 165 & 165 & 165 \\
\hline \multicolumn{2}{|l|}{ Cement } & 195 & 214 & 239 & 269 & 306 \\
\hline \multicolumn{2}{|l|}{ Fly ash (35\% as replacement) } & 105 & 116 & 128 & 144 & 165 \\
\hline \multicolumn{2}{|l|}{ Chemical Admixture(Kg/cum) } & 3.00 & 3.30 & 3.70 & 4.10 & 4.70 \\
\hline \multicolumn{2}{|l|}{ Fine Aggregate(Kg/cum) } & 856 & 824 & 789 & 743 & 693 \\
\hline \multirow{2}{*}{ Coarse Aggregate (Kg/cum) } & $20 \mathrm{~mm}$ & 666 & 667 & 666 & 667 & 662 \\
\hline & $10 \mathrm{~mm}$ & 447 & 448 & 447 & 448 & 444 \\
\hline
\end{tabular}

Table 6F. Mix proportions used for detailed trials using OPC mixed with $40 \%$ fly ash

\begin{tabular}{|c|c|c|c|c|c|c|}
\hline \multicolumn{2}{|l|}{ Mix Constituents ( kg) } & \multicolumn{5}{|c|}{ For One Cubic Meter } \\
\hline \multicolumn{2}{|l|}{ Water/cementitious ratio } & 0.55 & 0.50 & 0.45 & 0.40 & 0.35 \\
\hline \multicolumn{2}{|l|}{ Water } & 165 & 165 & 165 & 165 & 165 \\
\hline \multicolumn{2}{|l|}{ Cement } & 180 & 198 & 220 & 248 & 282 \\
\hline \multicolumn{2}{|l|}{ Fly ash ( $40 \%$ as replacement) } & 120 & 132 & 147 & 165 & 189 \\
\hline \multicolumn{2}{|l|}{ Chemical Admixture(Kg/cum) } & 3.00 & 3.30 & 3.70 & 4.10 & 4.70 \\
\hline \multicolumn{2}{|l|}{ Fine Aggregate(Kg/cum) } & 853 & 821 & 786 & 740 & 690 \\
\hline \multirow{2}{*}{ Coarse Aggregate (Kg/cum) } & $20 \mathrm{~mm}$ & 664 & 665 & 664 & 664 & 659 \\
\hline & $10 \mathrm{~mm}$ & 446 & 447 & 446 & 446 & 442 \\
\hline
\end{tabular}

Table 6G. Mix proportions used for detailed trials using OPC mixed with $45 \%$ fly ash

\begin{tabular}{|c|c|c|c|c|c|c|}
\hline \multicolumn{2}{|l|}{ Mix Constituents ( kg) } & \multicolumn{5}{|c|}{ For One Cubic Meter } \\
\hline \multicolumn{2}{|l|}{ Water/cementitious ratio } & 0.55 & 0.50 & 0.45 & 0.40 & 0.35 \\
\hline \multicolumn{2}{|l|}{ Water } & 165 & 165 & 165 & 165 & 165 \\
\hline \multicolumn{2}{|l|}{ Cement } & 165 & 181 & 202 & 227 & 259 \\
\hline \multicolumn{2}{|l|}{ Fly ash ( $45 \%$ as replacement) } & 135 & 149 & 165 & 186 & 212 \\
\hline \multicolumn{2}{|l|}{ Chemical Admixture(Kg/cum) } & 3.00 & 3.30 & 3.70 & 4.10 & 4.70 \\
\hline \multicolumn{2}{|l|}{ Fine Aggregate(Kg/cum) } & 851 & 818 & 784 & 737 & 687 \\
\hline \multirow{2}{*}{ Coarse Aggregate (Kg/cum) } & $20 \mathrm{~mm}$ & 662 & 663 & 661 & 661 & 656 \\
\hline & $10 \mathrm{~mm}$ & 444 & 445 & 444 & 444 & 440 \\
\hline
\end{tabular}




\subsection{Specimen Cast and Curing}

$150 \mathrm{~mm}$ cube specimens were cast for compressive strength. The specimens were kept at $27 \pm$ $2^{\circ} \mathrm{C}$ and relative humidity more than $90 \%$ for 24 hours initially. For accelerated curing the specimens were submerged in hot water immediately after demoulding in open cage, at different temperature regimes and for different time duration. After the completion of accelerated curing specimens were taken out from hot water and were kept in water at $27 \pm 2^{\circ} \mathrm{C}$ for $1 \frac{1}{2}$ hour. The specimens were tested for accelerated compressive strength after $1 \frac{1 / 2}{2}$ hour as per IS 516 . For 28 days' compressive strength, the specimens were kept in water at $27 \pm 2^{\circ} \mathrm{C}$ for curing up to 28 days.

\section{Methodology adopted to develop empirical relationship}

Following steps were followed for the development of empirical relationship between accelerated compressive strength and 28 days moist cured compressive strength:

i. All the trial results of accelerated compressive strength and 28 day compressive strengths are tabulated and standard deviation is calculated.

ii. Two categories of data sets corresponding to each temperature regime are taken for analysis of the trial results as given below.

Category 1: $\quad$ Hot water at $90^{\circ} \mathrm{C}$ for 7.5 hours

a) $20-35 \%$ fly ash replacement at $90^{\circ} \mathrm{C}$ and 7.5 hours

b) $40-45 \%$ fly ash replacement at $90^{\circ} \mathrm{C}$ and 7.5 hours

Category 2: $\quad$ Hot water at $82^{\circ} \mathrm{C}$ for 20 hours

a) $20-35 \%$ fly ash replacement at $82^{\circ} \mathrm{C}$ and 20 hours

b) $40-45 \%$ fly ash replacement at $82^{\circ} \mathrm{C}$ and 20 hours

iii. Best fit line is plotted and expected 28 days strength is calculated by this best fit line equation.

iv. Upper and lower control limits were fixed as per criteria given below and the points above/below upper/lower limits were treated as outliers

Criteria for fixing outliers:

a. Mean \pm Se (Standard Error) X 2.5 (considering $98 \%$ confidence level)

b. $\quad$ Mean $\pm 15 \%$

(both the criteria were nearly matching)

It was seen that total outliers were less than $10 \%$ of total data.

v. Data beyond the upper limit and lower limit was eliminated.

vi. The best fit line was plotted again by adopting the same procedure as given in step no. (iii) \& (iv).

vii. In the case of hot water procedure using temperature regime of $90^{\circ} \mathrm{C}$ for 7.5 hours, the best fit line was lowered by $8 \%$ to bring more than $90 \%$ data above this line as shown in Fig.1 and Fig. 2.

viii. In the case of hot water procedure using temperature regime of $82^{\circ} \mathrm{C}$ for 20 hours, the best fit line was lowered by $10 \%$ to bring more than $90 \%$ data above this line as shown in Fig.3 and Fig. 4. 
ix. The line (after lower down) where less than $10 \%$ data remain below is adopted for calculating the expected 28 days compressive strength.

The validation of equation was done for temperature regime $90^{\circ} \mathrm{C}$ for 7.5 hours only as the best fit line was lower down $8 \%$ only in comparison to $10 \%$ in the case of temperature regime of $82^{\circ} \mathrm{C}$ for 20 hours, to bring more than $90 \%$ results above best fit line plotted.

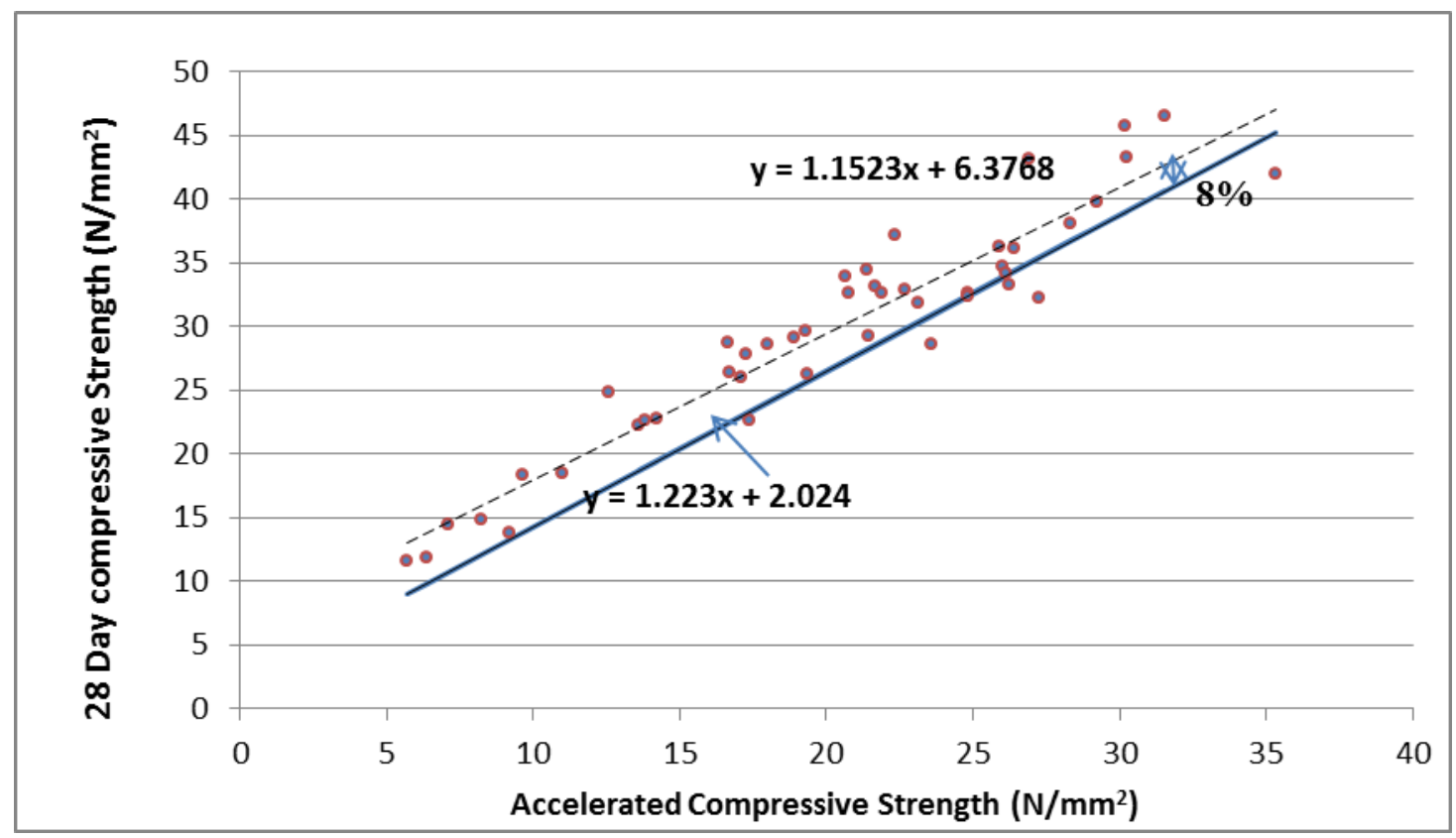

Fig. 1. Proposed $90^{\circ} \mathrm{C} 7.5$ hours graph for PPC and OPC + Flyash $(15 \%$ to $<35 \%)$

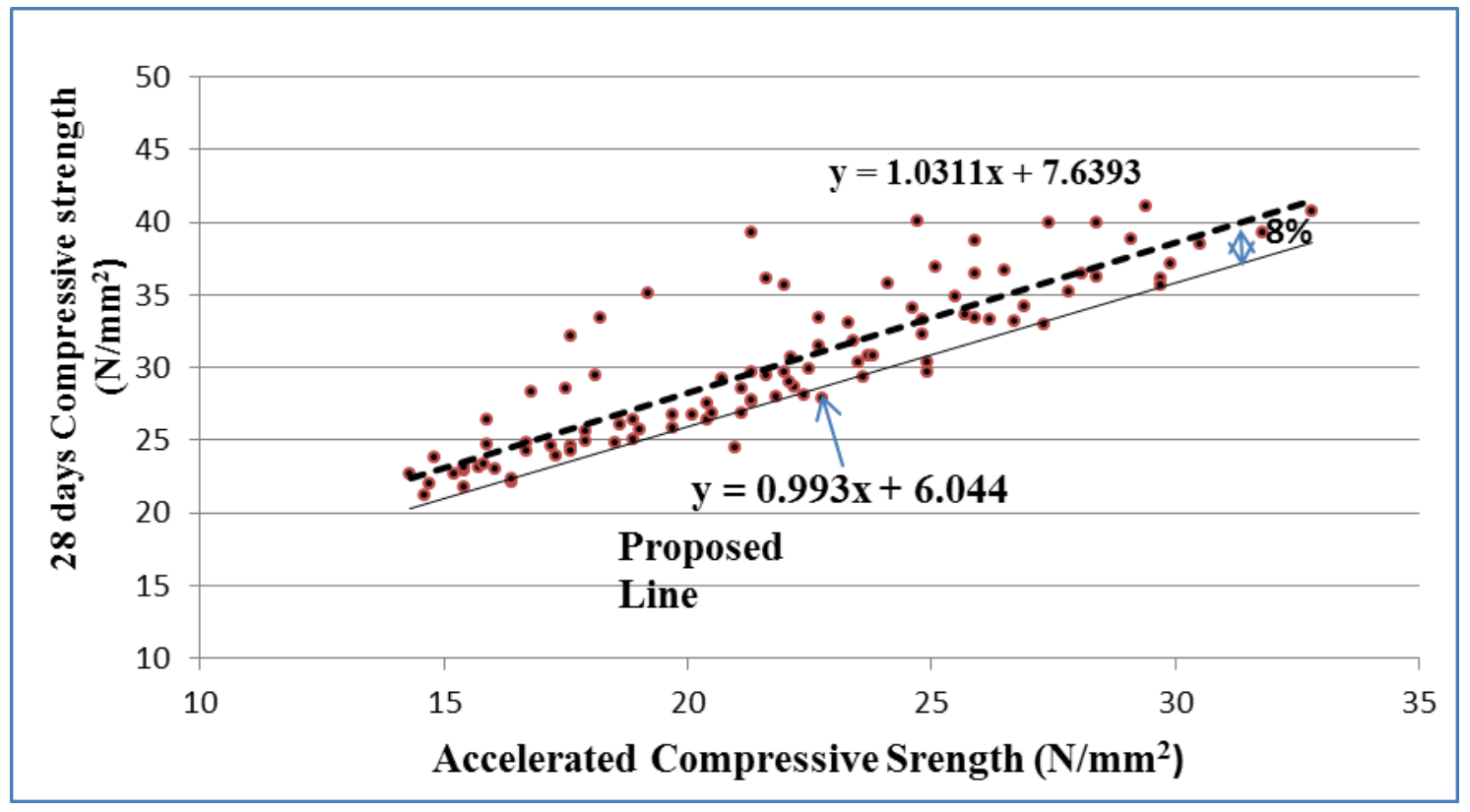

Fig. 2. Proposed $90^{\circ} \mathrm{C} 7.5$ hours graph for PPC and OPC + Flyash ( $>35 \%$ to $45 \%$ ) 


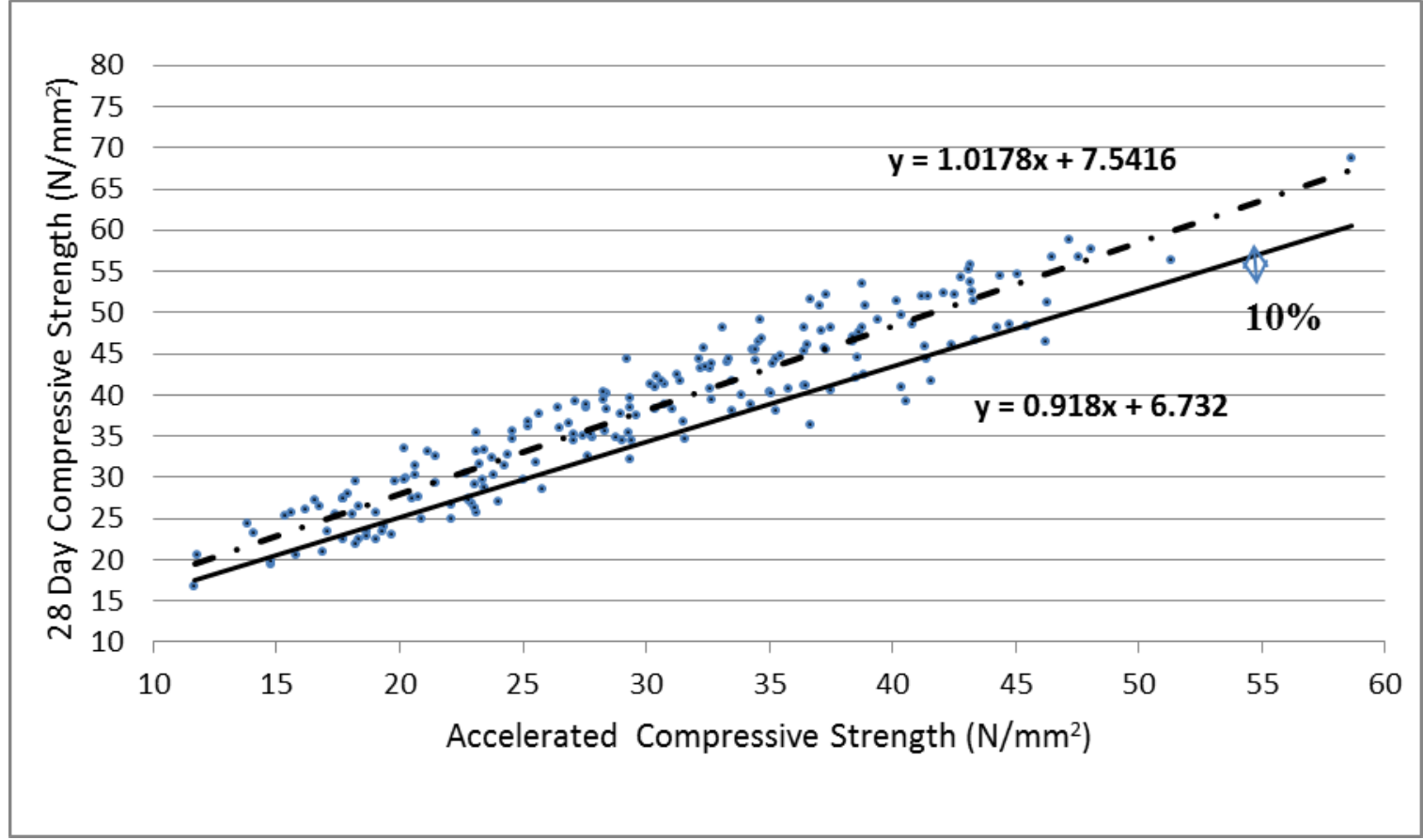

Fig. $3.82^{\circ} \mathrm{C} 20 \mathrm{~h}$ graph for PPC Cement and OPC + flyash $(20 \%$ to $<35 \%)$

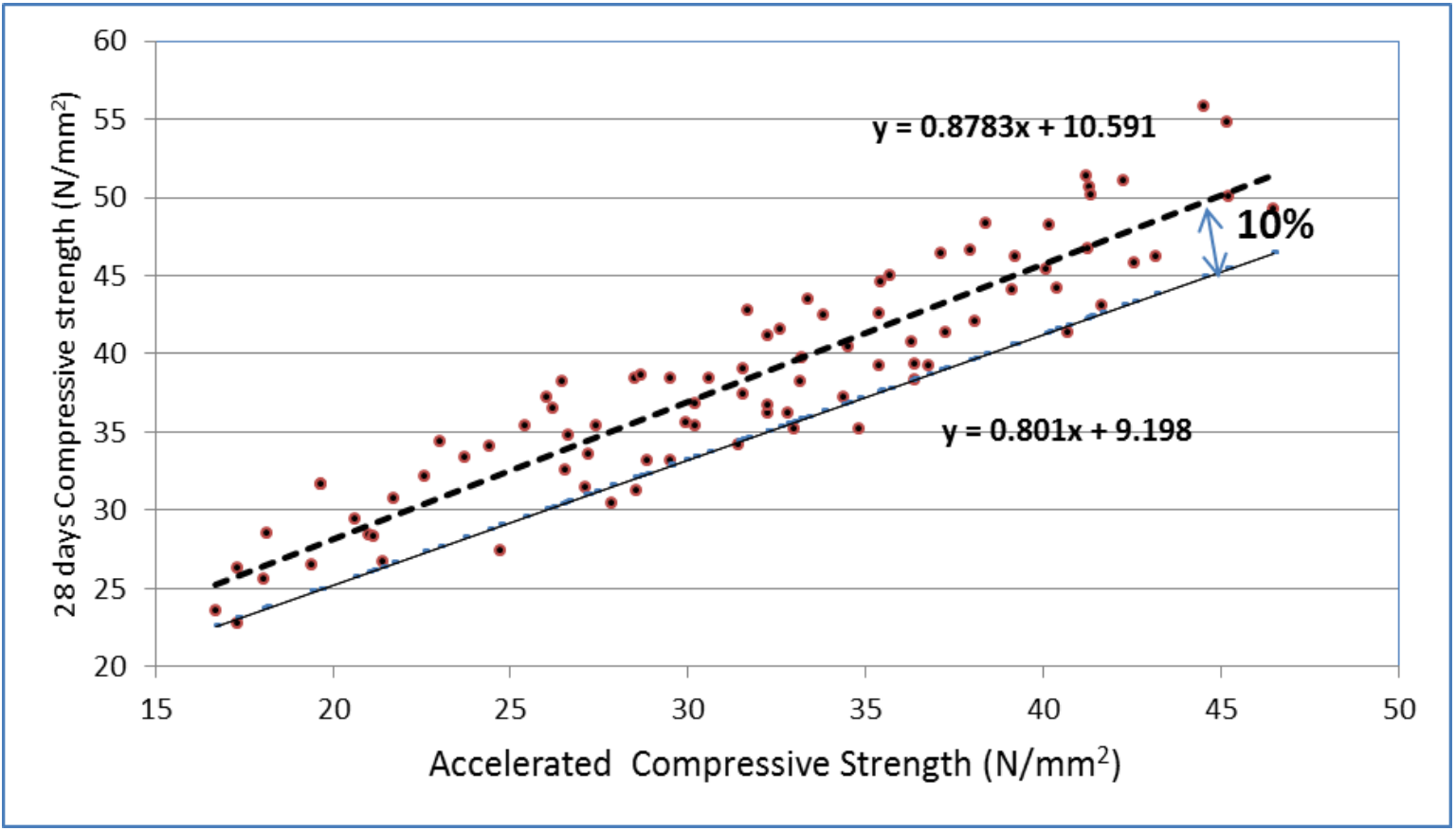

Fig. 4. 820C 20h graph for PPC and OPC + Flyash (>35\%-45\%)

\section{Conclusions}

Early prediction of 28 days compressive strength results through existing codal provision is not possible for concrete mixes having Pozzolana like fly ash, due to the effect of their physical and chemical properties on the rate of strength gain. Based on validation of developed relationships, it is concluded that for PPC and at different replacement level of OPC by flyash (20\% to $45 \%$ ), the elevated temperature curing regime i.e. $90^{\circ} \mathrm{C}$ for 7.5 hours can be adopted for prediction of expected 28 days compressive strength. 
However, since the rate of strength development differs with the level of flyash replacement and therefore, for the following two cases, two separate empirical relationships can be adopted:

a. For the mixes made with PPC and OPC with flyash up to $35 \%$

b. For the mixes made with OPC and flyash more than $35 \%$ up to $45 \%$.

Mathematical equations for early prediction of 28 days compressive strength of concrete are proposed separately for the mixes having PPC cement, OPC mixed with fly ash (20\% to 35\%) and the mixes having OPC mixed with fly ash more than $35 \%$ and up to $45 \%$. These mathematical equations give the confident level around $90 \%$.

The mathematical equations to estimate the 28 days compressive strength of concrete, cured at $90^{\circ} \mathrm{C}$ for 7.5 hours for mixes having PPC, OPC mixed with fly ash $20 \%$ to $35 \%$ is-

$\mathrm{f}_{\text {exp }} 28=1.223 \mathrm{f}_{\text {acs }}+2.024$

and mixes having OPC mixed with fly ash more than $35 \%$ and up to $45 \%$ is-

$\mathrm{f}_{\exp } 28=0.993 \mathrm{f}_{\mathrm{acs}}+6.044$

Where: $\quad \mathrm{f}_{\exp } 28=$ Expected 28 days' compressive strength of concrete in $\mathrm{N} / \mathrm{mm}^{2}$

$\mathrm{f}_{\text {acs }}=$ Accelerated compressive strength in $\mathrm{N} / \mathrm{mm}^{2}$

\section{References}

ACI 214.1R (1987). Use of Accelerated Strength testing, ACI manual of Concrete practice.

Amritkar, S., \& More, N. (2015). Statistical Modeling To Forecast The Strength Of Concrete Using Accelerated Curing, International Journal Of Research In Engineering And Technology, 4, 11.

ASTM C 684 (1999). Standard Test Method for Making, Accelerated Curing and Testing Concrete Compression Test Specimens

Bhanja, S., \& Pan, S. (2013). Modified Water cement ratio law for fly ash concrete\| The Indian Concrete Journal, 87, 21-28.

BS 1881(1983). Part 112 , Methods of Accelerated Curing of Test Cubes, British Standards.

CSA A23.1 (1970). Accelerating the curing of cylinders and determining their compressive strength Canadian Standards Agency.

IS- 456 (2000). Indian standard code of practice for plain and reinforced concrete, Fourth Revision, IS: 456-2000, Bureau of Indian standards, New Delhi.

IS- 9013 (1978). Method of making curing and determining compressive strength of accelerated cured concrete test specimens.

IS: 1489 (2015). Part 1, Specification for Portland Pozzolana Cement (fly ash based), Bureau of Indian Standards, New Delhi.

IS: 269 (2015). Ordinary Portland Cement - Specification, Bureau of Indian Standards, New Delhi.

IS: 3812 (2013). Part 1, Specification for pulverized fuel ash, Bureau of Indian Standards, New Delhi.

IS: 383 (2016). Specification for coarse and fine aggregates from natural sources for concrete, Bureau of Indian Standards, New Delhi.

IS: 9103 (1999). Specification for Concrete admixture, Bureau of Indian Standards, New Delhi.

Jayadevan, V., Valsalakumary, V. R., \& Sufeera, O. B. (2014). Reliability of accelerated curing techniques for speedy design of concrete mixes-An appraisal of IS 9013: 1978 code. Indian Concrete Journal, 5760. 
Jayanta, N. C., \& Jaydeep C. (2016). Development of Strength Prediction Models of 28 days Fly Ash Concrete Strength by Accelerated Curing Method, International Journal of Scientific \& Engineering Research, 7(4), 83-86.

Khan, M. A., Chowdhry, M. A., Javed, A., Ahmed, M. L., \& Kanwal, H. (2019). Strength prediction model for accelerated cured fly-ash based concrete. Mehran University Research Journal of Engineering \& Technology, 38(4), 1057-1066.

Krishna, R., Kumar, R. P., \& Khan, A. M. (2010). A study on the influence of curing on the strength of a standard grade concrete mix. Facta Universitatis-Series: Architecture and Civil Engineering, 8(1), 2334.

Nikitha, P. \& Kameswara R. B. (2019). Accelerated Method of Concrete Mix Proportioning by Incorporating Fly Ash and Silica Fume, International Journal of Recent Technology and Engineering, 7(6C2).

Shah, P., \& BhavnaShah, S. (2011). Development of Mathematical Model to Predict Early Age Strength for Blended Cement through Accelerated Curing. In Published: National Conference on Recent Trends in Engineering \& Technology on May.

Shelke, N. L., \& Gadve, S., (2013). Prediction of compressive strength using Accelerated Curing", International Journal of Pure \& Applied Research in Engineering \& Technology, 8(1), 90-99.

Tokyay, M. (1999). Strength prediction of fly ash concretes by accelerated testing. Cement and concrete research, 29(11), 1737-1741.

Udoeyo, F. F., Brooks, R., Udo-Inyang, P., \& Nsan, R. O. (2010). Early prediction of laterized concrete strength by accelerated testing. IJRRAS, 5(1), 10. 1345-1353. 